\title{
PUBERTY OR PASSION? THE REFERENT OF YMEPAKMO $\Sigma$ IN 1 CORINTHIANS 7:36
}

\author{
Bruce W. Winter
}

\begin{abstract}
Summary

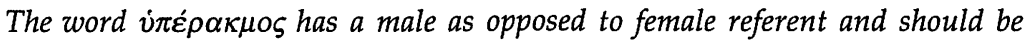
translated 'full of sexual passion'. It is based on a survey of this term in ancient

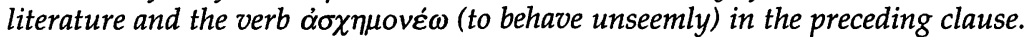
It is further re-enforced by the grammatical constructions following the particles

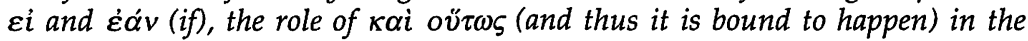
following statement, the meanings of $\theta \dot{\varepsilon} \lambda \eta \mu \alpha$ (sexual desire) and $\dot{\alpha} v \dot{\alpha} \gamma \kappa \eta$ (sexual necessity) in verse 37 and the Greek word for 'past one's prime', i.e., $\pi \alpha \rho \alpha \kappa \mu \eta$ '.
\end{abstract}

\section{Introduction}

The traditional rendering of the clause 'if she be past the flower of her age' (1 Cor. 7:36) has long created unease among commentators. For example, in their early twentieth-century commentary, Robertson and Plummer suggested that " past the

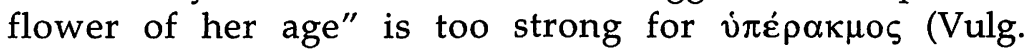
superadulta)'.1 According to a late first-century AD Ephesian doctor, Soranus, this was when menstruation, and thus childbearing, ceased (Gynaecology 1.20). It occurred after the age of forty and not later than fifty. ${ }^{2}$ If $\dot{v} \pi \dot{\rho} \rho \alpha \mu о \varsigma$ means 'past her prime', then what Paul is saying was that it was only after the age of forty Christian women were permitted to marry!

\footnotetext{
${ }^{1}$ A. Robertson and A. Plummer, First Epistle of St Paul to the Corinthians (ICC; Edinburgh: T \& T Clark, 1914²) 159.

${ }^{2}$ D.W. Amunsen and C.J. Diers, 'The age of menopause in classical Greece and Rome', Human Biology 42 (1970) 79-88; A. Wallace-Hadrill, 'Family and Inheritance in the Augustan Marriage Laws', Proceedings of the Cambridge Philological Society n.s. 27 (1981) 59; and J.F. Gardner, Women in Roman Law and Society (London: Croom Helm, 1986) 178-79.
} 
Some commentators have also expressed uncertainty about whether the issue related to the woman or the man-the

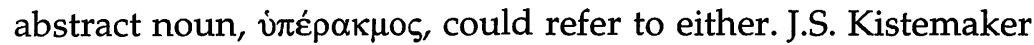
recently concluded that the word means 'past marriageable age' if the reference is to the woman. If it is to the man, then it is to one 'with strong passions' 3 and he cites as support the comments of $B A G D$. They themselves suggest that depending on the meaning of $\gamma \alpha \mu i \zeta \omega$, the term refers either to the woman 'past one's prime, past marriageable age, past the bloom of youth' or to the man 'in which case vं $\pi \varepsilon \rho$ is not to be understood in the temporal sense, but expresses intensification' because $\alpha \kappa \mu \eta$ refers to 'the highest point or prime of a person's development'. They therefore deduce that the word means 'with strong passions'. ${ }^{4}$ However they cite only one specific reference where the term refers to puberty-a possible rendering they proceed to ignore. They have built their case on a deduction based on the role of $\dot{v} \pi \dot{\rho} \rho$. Translators themselves are unsure. The Revised English Bible reflects the uncertainty of the gender referent giving 'his passions are strong' and for an alternative rendering 'she has reached puberty'.

J.C. Hurd was also unable to decide whether the word refers to 'past the bloom of youth' for the woman, or 'with strong passions' (of the man). 'There seems to be evidence in Greek literature that either meaning is possible. If the word is genuinely ambiguous, then the immediate context favours referring it to the man, since he is the subject of the preceding verb. ${ }^{5} \mathrm{~B}$. Witherington proposes that the young man is full of strong passions for his wife-to-be and that the reference of

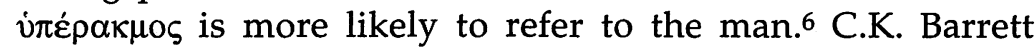

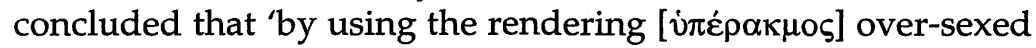
it determines the meaning of a difficult and ambiguous

3S.J. Kistemaker, 1 Corinthians (Grand Rapids: Baker, 1993) 251.

${ }^{4} B A G D, 839$.

${ }^{5}$ J.C. Hurd Jr., The Origin of 1 Corinthians (Macon: Mercer University Press, $1983^{2}$ ) 173. He, like other commentators, cites no examples.

${ }^{6} \mathrm{~B}$. Witherington III, Women in the Earliest Churches (SNTSMS 59;

Cambridge: Cambridge University Press, 1988) 39, 239 n. 80. 
sentence in what seems the most probable but is certainly not the only possible sense. ${ }^{\prime 7}$

W. Deming, in his recent monograph, translates the term as 'over the limit' as in a sexual sense. He notes in passing the alternative rendering of 'over marriageable age' and also draws attention to the deductions of $B A G D .8$ Those who wish to argue that the reference is to being over the age to marry are faced with the fact that, in the early empire, Augustus passed legislation which actually specified that this was after the age of fifty-five years. ${ }^{9}$

It is somewhat puzzling that J.H. Moulton and G. Milligan's entry on vं $\varepsilon \dot{\rho} \alpha \kappa \mu \rho \varsigma$ did not discuss the actual word, even though at the time of compiling this work a papyrus had already been published which provided an example, (PSI 6.666). ${ }^{10}$ Rather, they cite examples of the use of i $\pi \varepsilon \rho \varepsilon \tau \dot{n}$ s which meant 'of full age'.11 They indicate that this latter term is not cited in the eighth edition of Liddell and Scott, although the latter remedied this in the ninth, and rendered it 'past the age'. Moulton and Milligan believed that it was used of those who were no longer liable for the poll tax. There is, however, no justification for regarding $\dot{v} \varepsilon \rho \varepsilon \tau \eta^{\prime} s$ as a synonym of

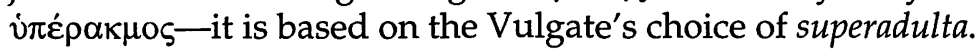

In order to explore the meaning and the referent of the

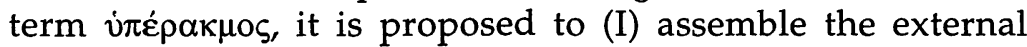
evidence for its meaning; (II) examine the meaning of $\dot{\alpha} \sigma \chi \eta \mu$ ové $\omega$ in order to understand the ways in which a person could have been 'behaving in an unseemly fashion' towards another; (III) show that, in the clause which follows i $\pi \dot{\varepsilon} \rho \alpha \kappa \mu$,

\footnotetext{
${ }^{7}$ C.K. Barrett, The First Epistle to the Corinthians (London: A \& C Black, 19712) 182.

${ }^{8} \mathrm{~W}$. Demming, Paul on Marriage and Celibacy: The Hellenistic Background of 1 Corinthians 7 (SNTSMS 83; Cambridge: Cambridge University Press, 1995) 206 n. 390.

${ }^{9}$ Wallace-Hadrill 'Family and Inheritance', 59.

${ }^{10} \mathrm{~J} . \mathrm{H}$. Moulton and G. Milligan, The Vocabulary of the Greek Testament (London: Hodder and Stoughton, 1930) 652. They cite PSI = Papyri Greci e Latini: Pubblicazioni della Società Italiana per la ricerca dei Papiri in Egitto (Florence: Arani, 1920) vol. 6.

11P.Ryl. 105 l. 11 (AD 136), P.Oxy. 1030 l. 8 (AD 212), P.Oxy. 1198 l. 9 (AD 150), P.Giss. 59 iv. l. 14 (AD 119-120).
} 


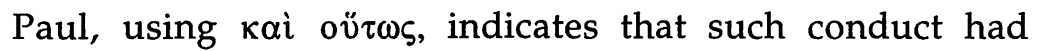
inevitable consequences because of sexual impropriety; (IV) compare the conditions applied in 7:37 for not marrying by understanding the meaning of 'necessity' and 'having control over one's desire'; and (V) argue that the referent was male and not female.

\section{Extra-biblical Meanings of vं $\pi \varepsilon ́ p \alpha \kappa \mu \varsigma \varsigma$}

Is there concrete evidence for the meanings suggested, and is it possible to determine whether the referent is female or male? In this instance New Testament studies have been long on discussion but short on supporting evidence. While the attestation of $\dot{v} \pi \dot{\varepsilon} \rho \alpha \mu \mu_{\varsigma}$ is considered relatively scarce, important evidence is available on the Thesaurus Linguae Graecae CD Rom.

First, there are examples of cognates drawn from the third and first centuries BC. In the former era a non-literary text reads 'and you know that...the vines surpass in vigour [or]

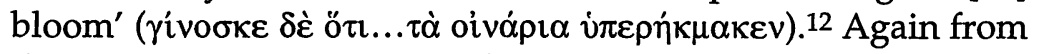
the same century in Myro 2, the cognate verb is used to refer to the excessive energy in human beings-those who 'presented an appearance of vigour exceeding that of a slave' ( a well known saying, for it is repeated in the late secondcentury work of Athenaeus. ${ }^{13}$ In what is thought to be a first-

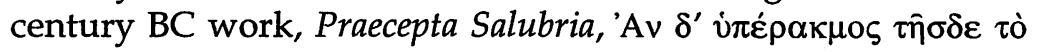
$\pi \lambda \hat{\eta} \rho \varepsilon \varsigma \sigma \kappa o ́ \pi \varepsilon \imath$ refers to someone who is on the lookout to be satiated- $\tau$ ò $\pi \lambda \hat{\eta} \rho \varepsilon \varsigma$ has sexual connotations. ${ }^{14}$

There are also late first-century and early secondcentury works which bear witness to the meaning of the word and used only a half a century after Paul wrote 1 Corinthians.

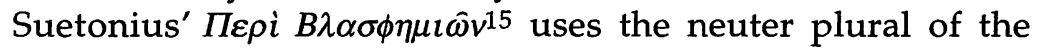

12PSI 6.666, l. 18 (iii BC), a meaning given by Liddell and Scott, $1845^{2}$.

${ }^{13}$ C. Müller (ed.), Fragmenta Historicum Graecorum (Paris: Didot, 1867) IV. 460 and Deipnosophistae 657d.

${ }^{14}$ Lines 11, 18. On the sexual connotations, see e.g. Epicurus, Sententiae, 40.

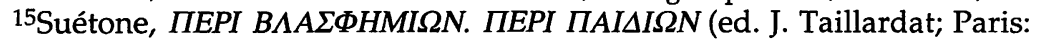
Les Belles Lettres, 1967) III. 69. Cf. Eustathius, Od., 2.265-6 (12th century 
noun as an adverb. The ones who have outrun the age of youth $(\dot{\varepsilon} \kappa \delta \rho \circ \mu \alpha \dot{\alpha} \varepsilon \varsigma)^{16}$ are referred to as 'those who are undisciplined

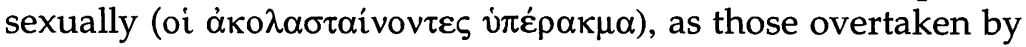
time and yet now behaving like youths with their first-time beards', i.e., promiscuously. 17 This example is important for it uses another term to describe those who have 'outrun the age of youth', while the adverbial form refers to a person who is sexually active.

From the late first century AD comes evidence from an Ephesian doctor concerning women. Soranus, who was trained in Alexandria and also practised in Rome, discusses in his extended work, Gynaecology, the intensity of the menstrual flow. 'For in very rare cases limited "to those women past puberty" [after the onset of menstruation] a concentrated flow

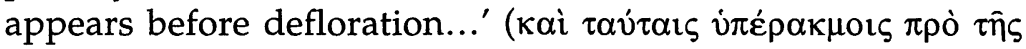

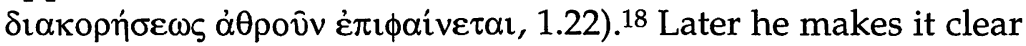
that the time to begin sexual intercourse is after the onset of puberty which, he observed, was at the age of fourteen, outlining the risks for those who have intercourse before

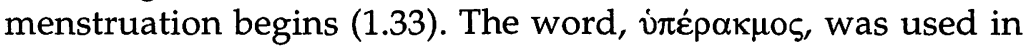
this instance as a medical term to describe females who were past puberty (i.e., fourteen years old), but certainly not past child-bearing age. ${ }^{19}$

A Christian writer of the fourth century, Epiphanius, translates 1 Corinthians 7:36, 'If any man thinks that he behaves himself uncomely towards his virgin, and need so require, let her marry; she has not sinned'. This rendering is germane to his

AD) where he cites Suetonius by stating that this phrase refers to those who have passed the age of youth, but clearly they are not past menopause nor are they impotent. This late work is invaluable because the author collected old scholia and lost works of earlier scholars and lexicographers.

${ }^{16}$ Eubulus (IV BC) 11; cf. Eustathius, 1915.20.

17 For a discussion of the behaviour when élite young men took the toga virilis, see my 'Gluttony and Immorality at Élitist Banquets: The Background to 1 Corinthians 6:12-20', Jian Dao 7 (January, 1997) 55-67.

${ }^{18}$ For an English translation, see O. Temkin, Soranus' Gynecology (Baltimore: Johns Hopkins University Press, 1956).

${ }^{19}$ Barrett (The First Epistle to the Corinthians, 184) believes that the term does not mean 'at the age of puberty'. 
refutation of certain heretics (Against Apostolics) who reject marriage per se. Epiphanius uses the phrase 'concerning marriageable women' ( $\pi \varepsilon \rho i$ i $\pi \alpha \rho \theta \varepsilon ́ v \omega v ~ v ं \pi \varepsilon \rho \alpha ́ \kappa \mu \omega v)$ for those who had not sworn a vow of virginity to God. He specifically states that these 'marriageable women had remained virgins in their prime ( $\dot{\varepsilon} v \tau \hat{\eta} \dot{\alpha} \kappa \mu \hat{\eta})$ not because of a vow but because they cannot find men for marriage'. Only slightly later he uses the cognate of $\dot{v} \varepsilon \dot{\varepsilon} \alpha \kappa \mu \mathrm{s}$ to mean 'to be sexually passionate''these [women] who are sexually passionate would fall into

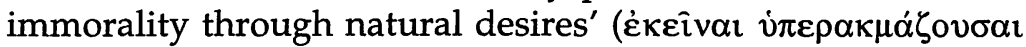

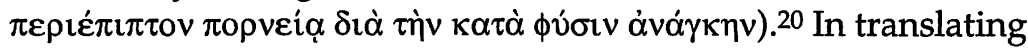
the word again only fourteen lines later, F. Williams surprisingly renders the same verb $\dot{\tau} \pi \varepsilon \rho \alpha \kappa \mu \alpha \zeta \zeta \omega$ as 'past their prime'.21 This context relates to fathers who kept their daughters home for a long time because of a dearth of marriageable Christian men. However, the text nowhere implies that the women commit fornication in old age (i.e., 'past their prime'). Rather, because they were not married, there was the danger that they could fall into this sin because of the inappropriate use of natural sexual drives.

Hesychius, the fifth-century $A D$ lexicographer, gave synonyms for ancient literary sources which had been substituted by later editors. He indicated that $\kappa \alpha \tau \rho \rho \gamma \hat{\alpha} v$ is synonymous with $v \pi \varepsilon \rho \alpha \kappa \mu \alpha \zeta \varepsilon \imath v .22$ The former verb refers to the

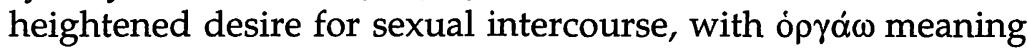

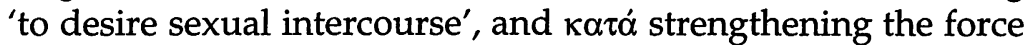
of the verb, according to Liddell and Scott.

In seeking to arrive at the meaning of i $\pi \varepsilon \dot{p} \alpha \kappa \mu \mathrm{s}$, it is also important to note that another term was used to describe

${ }^{20}$ Haereses, 2.385. l. 10, l. 24. G.W.H. Lampe, A Patristic Greek Lexicon (Oxford: Clarendon Press, 1968) 1437 wrongly cites both passages from Epiphanius as an example of the use of the verb 'to be past the prime' and the noun 'past the prime' of 'virgins' and also refers to 1 Cor. 7:36.

${ }^{21} \mathrm{~F}$. Williams, The Panarion of Epiphanius of Salamis, Books II and III (Nag Hammadi and Manichaean Studies Vol. xxxvi; Leiden: E.J. Brill, 1994) 118. Williams renders the noun and the verb inconsistently. vं $\pi \dot{\varepsilon} \rho \alpha \mu$ os he rightly translates as 'marriageable women' in the slightly earlier discussion and the verb as 'being past their prime'.

22kappa, 1845.1. See also Suda, kappa, 1089.1. 
those 'past their prime', 23 and that is $\pi \alpha \rho \alpha \kappa \mu \eta$ with the cognate, $\pi \alpha \rho \alpha \kappa \mu \alpha \zeta \omega$. For example, in the late first-century and earlysecond century writings of Plutarch, it refers to those whose political power is waning; of people's wrath subsiding; of courage that is past its prime; of men who are old and past their prime; of those who are passing their prime; and to those experiencing the abatement of vigour caused by age. ${ }^{24}$ In Xenophon it describes beauty passing its prime. ${ }^{25}$ Alexander of Aphrodisias refers to being past one's prime when 'licentious activity of the body will cease [because of age]' ( $\tau \hat{\omega} \tau \hat{\eta} \nu \mu \dot{\nu} v$

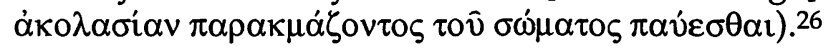

From these examples of $\dot{\tau} \varepsilon \dot{p} \rho \kappa \mu \varsigma \varsigma$ and its cognates a number of points emerge. Clearly the verbal form neither suggested that the person had reached menopause if a woman, nor impotence through age if a man. It was used to refer either to a woman who has reached puberty and therefore could engage in intercourse and safely conceive, or to the sexual drives or passions notionally of either sex. Usually it referred to the man, and then to indicate the danger of being entrapped by immorality through his natural sex drives.

Even the earlier, non-sexual references do not imply in any way a diminution of energies, but rather the exact opposite. Liddell and Scott, in their first edition of 1843, translated the term to mean 'beyond the bloom of youth' citing only 1 Corinthians 7:36. In the latest edition, they rendered the term as 'sexually well developed' citing in support 1 Corinthians 7:36, and Soranus 1.22.27 However, the above survey of additional primary sources shows that Liddell and Scott have arrived at their conclusion on the basis of limited evidence-one occurrence in a gynaecological textbook. ${ }^{28}$

${ }^{23} \mathrm{Cf}$. T.C. Edwards, Commentary on the First Epistle to the Corinthians (London: Hodder \& Stoughton, 1897), 200 who incorrectly states 'The

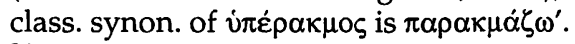

${ }^{24}$ Brut., 8.3, 21.1, Arat., 36,3, Oth., 12.3, Moralia, 364B, 453B.

${ }^{25}$ Symposium, $4.17,8.14$,

26In Aristotelis topicorum, 223.23 (c. AD 200).

${ }^{27}$ Liddell and Scott see exoletus as the Latin equivalent of $\dot{\pi} \dot{\varepsilon} \rho \alpha \kappa \mu$ ऽ wrongly following J.J. Wetstein, H KAINH $\triangle I A \Theta H K H$ (1752) II, 131.

${ }^{28}$ For an important discussion of some of the inadequacies of Liddell and Scott and examples for such a contention, see J. Chadwick, Lexicographica 
Attempts by lexicographers to construct a meaning for

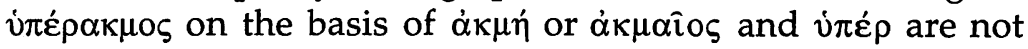
linguistically certain, because vं $x \varepsilon \dot{\rho}$ can have two meanings. Paul's term does not refer to those women who were past childbearing age, if indeed the reference is to a woman (which it

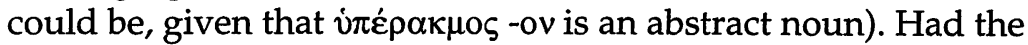
latter been the case, then the cognate of $\pi \alpha \rho \alpha \kappa \mu \eta \dot{~ a n d ~ n o t ~}$

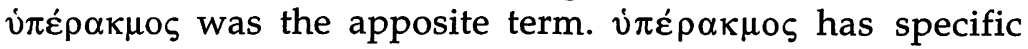
meanings in the semantic field of sexuality. It refers either to the reaching of puberty and reproduction for women or sexual passion for men.

\section{Unseemly Behaviour towards the Betrothed}

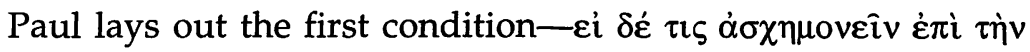

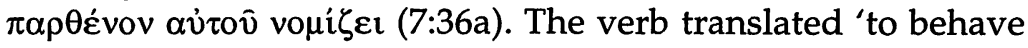

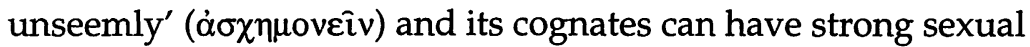
innuendoes. ${ }^{29}$ Plutarch, writing in the late first century AD, records that Philip of Macedonia was sitting down with his tunic pulled up in 'an unseemly way' exposing himself in front of slaves. The person who pointed this out to Philip was declared to be a true friend indeed. ${ }^{30}$ Cato's wife was divorced because of her 'unseemly behaviour' (i.e., her adultery), 31 and it is said that a young unmarried girl faced her 'unseemly behaviour' (i.e., fornication), with decorum by undergoing an abortion.32 Plutarch also makes reference to 'sundry amours, idle amusements with wine and women and other unseemly

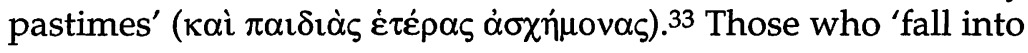

Graeca: Contributions to the Lexicography of Ancient Greek (Oxford: Clarendon Press, 1996).

${ }^{29}$ The cognate noun was also used as an euphemism for $\alpha$ idoiov and the LXX uses the latter term in Lev. 18:7-17 on a number of occasions. It is refers to uncovering 'the nakedness' of a number of persons with affinity relationships.

30Moralia 178D.

${ }^{31}$ Cato Minor, 24.3

${ }^{32}$ 'Sayings of the Spartans', $235 \mathrm{C}$ and in the same discourse reference is made to 'keeping brothels and 'other unseemly pursuits', 236B.

33Dion, 7.4 
passions $\left(\pi \alpha^{\prime} \theta \eta\right)$ and $\sin (\alpha \mu \alpha \rho \tau i \alpha \varsigma) \ldots$ act discreditably

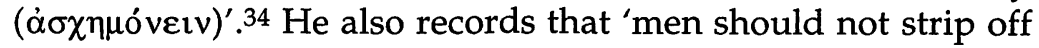
their clothes [in the baths] with women' (which was seen to be 'an impropriety') nor 'would a hetaira allow her lover to behave "improperly" beneath the portrait of Xenocrates who was famous for his chastity'.35 These uses in Plutarch are not confined to sexuil improprieties. Those who 'instantly interrupt with contradictions, neither hearing nor being heard, but talking while others talk, behave in an unseemly manner'; many gross 'improprieties' in the matter of listening and flattering friends are all considered 'unseemly'. The term can also describe an inadequate suitor as one without power and glory; a wife who controlled her husband; drunkenness; hunger; begging; undesirable people; spitting in a person's face; and those seen as cutting a sorry figure in polite society. ${ }^{36}$

Epictetus, a contemporary of Plutarch, uses $\dot{\alpha} \sigma \chi \eta \mu \nu \varepsilon \dot{c} \omega$ to refer to a person who 'disgraced himself naked and out of doors'. Its cognate is used to describe sleeping beside a beautiful woman and having strong desires-behaviour classed among the 'unseemly deeds' Epictetus condemns. ${ }^{37}$

Dio Chrysostom, also a contemporary of Plutarch, says of those who became dissolute and drunk at a private banquet, where 'after dinners' - as they came to be known-included sexual intercourse with courtesans, were behaving in an 'unseemly' way. A courtesan was declared 'indecent' because she uttered licentious phrases from her chamber. ${ }^{38}$ The word

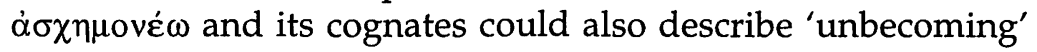
or 'inappropriate' behaviour, judged so by the norms of that society. ${ }^{39}$

34'How to study poetry', $23 \mathrm{E}$.

35 Fragments, 85, 97.

36 'How to listen to lectures' 39C, 45E-F; 'On compliancy' 532E 'Advice to bride and groom', 142E; 'Table Talk', 620D; 'On common conceptions', 1067E; 'Sayings of the Spartans', 235E; Phocion, 36.3; 'How to profit from one's enemies', 88E and 92F.

${ }^{37}$ Diss. 22.15.3, 4.9 .5 .

${ }^{38}$ Dio Chrysostom, Or. 30.41, 40.29. Cf. also unbecoming table manners at a banquet, Or. 30.35 .

${ }^{39}$ Used of the city fathers of Rhodes who were 'recycling' statues of deceased benefactors, Or. 31.68, 108, 119, 158; behaving in a disorderly 
Josephus used the term to describe the unseemly behaviour of the lovers Salome and Syllaeus in the court of Herod. He explicates this by recording that 'passions clear by their gestures and looks' resulted in a sexual liaison. Elsewhere what was done to statues which were then carried into a brothel was described as 'things too indecent to be reported'. He also notes the behaviour of a Roman soldier in the temple guard at the Passover in Jerusalem who exposed himself and stooped down in an 'indecent' attitude. 40

Non-literary sources also carry a variety of meanings. 41 One pertinent to our investigation describes the actions of a man who kept a woman in his room and would not allow her out, even though she was free born, as a [sexual] impropriety. ${ }^{42}$

The survey of literary writers and non-literary sources contains some eighty-seven occurrences of this word and its cognates and provides overwhelming evidence that, within the context of male and female relationships, the word 'to behave unseemly' has sexual connotations.

What did that conduct encompass? Musonius said that 'above all a woman must be chaste and self-controlled; she must, I mean, be pure in respect of unlawful love... and not a slave to desire'.43 In Paul's Corinth, where for one hundred and ten years not Greek but Roman culture had prevailed, the Latin term pudicus is used of a sexually respectable male, i.e., one 'who did not do certain things', 44 although it is impossible to determine the exact parameters set for sexually admissible

fashion in the public place in Alexandria which no claims to high status could ameliorate, Or. 32.31, 39; Appian records Dolabella engaging in 'unseemly behaviour' as he talked about his public office immediately after the assassination of Julius Caesar, BC II, 18.

${ }^{40}$ AJ 16.223, AJ 19.357-8, BJ 224.

${ }^{41}$ Clothing appropriately for a journey, P.Zen. 59477; a begging letter from a shamed person is an indigent but educated scholar, P.Zen. 59599; shameful mistreatment of slave, P.Ryl. 144 (AD 38); a complaint of an insult and injury P.Ryl. 150 (AD 40); and an assault in a temple P.Tebt. (114 $\mathrm{BC})$.

42P.Oxy. 1837 (sixth century AD).

43Musonius, 'That women too should study philosophy' III, ll. 17-19.

${ }^{44}$ For an excellent discussion of this issue, see R.A. Kaster, 'The Shame of the Romans', APA 127 (1997) 4-5. 
conduct for men. S. Treggiari remarked that we know very little of the expected relationship the engaged couple were meant to develop before marriage. 'The virgin certainly needed to be protected from seducers, but the phobia of pre-marital sex with a sponsus does not seem to occur until the empire became Christian. Rather, the maiden was meant to warm to her future husband.' 45 She cites Ovid's Amores, 'Let me be read by the maiden who warms to see her betrothed', and notes that 'Ovid paints a picture of the degree of physical intimacy which a sponsus might expect'. ${ }^{46}$ That reference is to a woman who complains of the nervousness of her suitor. 'He woos me less boldly and seeks few kisses and calls me his in frightened voice', which hardly establishes her point. 47 Treggiari's own Tendez towards later Christianity must be weighed against the evidence of the earlier Roman requirement of sexual respectability, pudicitia. 48

Paul himself uses the cognate and its antonym in 1 Corinthians 12:23-24 to describe the private over against the presentable parts of the body. He discusses the organs of the body and then proceeds to note that the unpresentable parts ( $\tau \dot{\alpha}$ $\left.\dot{\alpha} \sigma \chi \eta_{\mu} \mu v \alpha\right)^{49}$ of the human anatomy (i.e., the reproductive organs) are treated with a greater modesty than the presentable ones $\left(\varepsilon \dot{v} \sigma \chi \eta_{\mu} \sigma \alpha\right)$. The Roman statues in Paul's Corinth portrayed women and men clothed which was different from the Greek tradition of the naked human form. 50

In 1 Corinthians 7:36a it appears to be the case that the unseemly conduct of the young men does not amount to actual

\footnotetext{
${ }^{45}$ S. Treggiari, Roman Marriage Iusti Coniuges from the Time of Cicero to the Time of Ulpian (Oxford: Clarendon Press, 1991) 159. $\pi \alpha \rho \theta \varepsilon$ é and not a biological description, Chadwick, Lexicographica Graeca, 228.

46Treggiari, Roman Marriage, 160.

47 Her. 21.195-6.

48Kaster, 'The Shame of the Romans', 9-10.

49 It also describes homosexual intercourse as 'shameless', Rom. 1:27.

${ }^{50}$ The museum on the excavation site in Corinth has examples of statues of Roman women with elaborate dresses and Augustus dressed as the magistrate offering up a libation. However, the statues of the two adopted sons of Augustus recovered from the Julian Basilica in Corinth are portrayed naked standing like Greek athletes, but because they were deceased they were treated as gods in the imperial cult.
} 
fornication which Paul refuses to countenance. At least he does not say so. He has already warned the Corinthians that they should not be deceived by this behaviour because those who persisted in this particular sin would have no inheritance in the kingdom (1 Cor. 6:9). He then proceeds to deal with young men's sexual escapades with prostitutes with whom they had established a 'one flesh' relationship. He accuses them of fornication and not adultery. We can therefore assume that they had reached the age where they had taken the toga virilis and were following the dictum of youth that 'all things were lawful' (1 Cor. 6:12-20). 51

However, in 1 Corinthians 7:36a Paul refers to a very important aspect of shame in Roman culture, i.e., shame felt when reflecting on one's personal conduct which had fallen short of one's own ideal.52 It was not simply guilt because of a sexual misdemeanour with other women but it was with, or towards, his betrothed-'he reckons he is behaving unseemly towards his betrothed'. This is Paul's first criterion.

Is the vagueness of what the young men were specifically doing an indication that Paul knows what is happening, or is he speculating? The former appears to be the case. The construction $\varepsilon i$ with the present 'indicative of reality' in 1 Corinthians 7:36 is translated by BDF as '[as you tell me]', (§372). This construction is contrasted with the following conditional clause introduced by $\dot{\varepsilon} \alpha v$ with the present subjunctive. In this case غ́x́ $v$ is not a synonymous particle for $\varepsilon \dot{i}$ which requires the present or perfect indicative. 53 'Eóv can be used to express an indefinite relation to a present reality; $c f$. 'if you should have many guides' (1 Cor. 4:15, §372), and the present subjunctive can refer to the future (\$373). BDF account for the use of the different particles and moods in 1 Corinthians $7: 36$ thus. The first conditional sentence notes what is happening-'as you tell $\mathrm{me}^{\prime}$ and the second has a future

51For my argument, see my 'Gluttony and Immorality at Élitist Banquets: The Background to 1 Corinthians 6:12-20', 55-67.

52Kaster, 'The Shame of the Romans', 5.

${ }^{53}$ Contra A.T. Robinson, A Grammar of the Greek New Testament in the Light of Historical Research (New York: Hodder and Stoughton, 1914 ) 1009-10. However, see n. 55. 
reference ( $\$ 372$ i.a). However there are examples within 1 Corinthians where $\dot{\varepsilon} \alpha v$ followed by the present subjunctive refers to the present (e.g., 4:15; 5:11). Concerning these two conditional sentences, Fee argues that 'Paul knew that an actual situation like this existed in the community' and in the second suggests it was 'reflecting something that might be so'. ${ }^{54}$ Rather it is the case that where $\varepsilon \dot{i}$ and $\dot{\varepsilon} \alpha \dot{v}$ follow each other 'one conjunction or the other manifestly proceeds from a different conception of the relation'. ${ }^{5}$ Here we have the perception of the Corinthians in the $\varepsilon i$ clause, followed by Paul's understanding of what happens in such instances in the $\dot{\varepsilon} \alpha$ one. The following clause would support this contention.

\section{The Consequences of Sexual Impropriety}

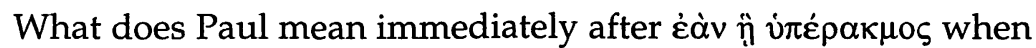

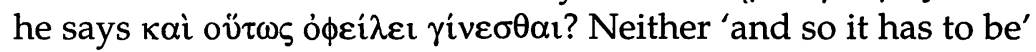
(NRSV) nor 'and he feels he ought to marry' (NIV) clearly explains what he is saying.

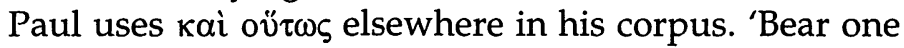
another's burdens and as a consequence you will fulfil the law of Christ' (future tense); 'sin came into the world through one man, and death through sin, and as a consequence spread to all men'; after concluding that whoever eats the bread and cup of the Lord in an unworthy manner will be guilty of profaning the Lord's body, he then commands that 'a man must examine

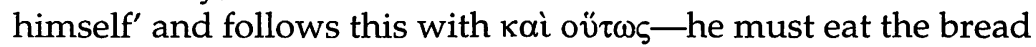
and drink of the cup (imperatives). Its reference to what precedes (i.e., self-examination), determines how he must now participate in the Lord's Supper compared with the way he had done so before (Gal. 6:2; Rom. 5:12; 1 Cor. 11:27-28). ${ }^{56}$ A highly apposite example is also found in 1 Corinthians 7:17a where Paul notes that, as the Lord has apportioned to each person and

${ }^{54}$ G.D. Fee, The First Epistle to the Corinthians (Grand Rapids: Eerdmans, 1987) 350 , nn. 11, 12.

${ }^{55}$ G.B Winer, A Treastise on the Grammar of the Greek New Testament (Edinburgh: T \& T Clark, 1870) 370-71 for a discussion of this based on ancient authors and NT examples including 1 Cor. 7:36.

${ }^{56}$ See also the only other two occurrences in the NT, Acts 7:8; 28:14. 
each is called by God, thus (ovi $\omega_{\zeta}$ ) he must walk. Naturally, as a consequence ('and thus', kai ov̈ $\tau \omega \varsigma$ ) he gives instruction in all the churches based on these truths $(7: 17 \mathrm{~b})$.

According to Liddell and Scott $\kappa \alpha i$ ov $\tau \omega \varsigma$ is to be translated 'even so' or 'even on this supposition'. They also note that ó $\phi \varepsilon i \lambda \varepsilon \imath$ when used with the infinitive equates to 'he/it

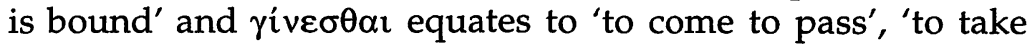

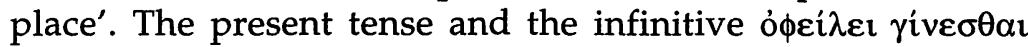
occur together on a number of occasions and there is implied a natural and a necessary nexus. ${ }^{57}$ BAGD draws attention to the use of oü $\omega_{\varsigma}$ without $\kappa \alpha i$ when indicating the moral after giving examples, and in support cite Aristotle. ${ }^{58}$ Paul is indicating what will happen of necessity because of such unseemly behaviour, i.e., his sexual drives have been inflamed. The apposite translation is 'and thus it is bound to happen'. 59

The construction of the clause with its introductory connective allows the interpretation suggested above, with 1 Corinthians 7:17 providing a comparable example. Given that the man has brought the relationship to this point, Paul allows that 'he must do as he wishes', i.e., 'they must marry'. Having already indicated that each person has his own charisma from God, which is either singleness or marriedness, and that it is better to marry than to burn, Paul assures him by repeating that in proceeding to marriage 'he is not sinning', and, as he said earlier, 'she is not sinning' (1 Cor. 7:7, 9, 28, 36).

57Sextus Empiricus, Pyrr. 3.63; Math. 10.133.6; Albinus, Epitome of Plato 9.1.8; Alexander of Aphrodisias, De Fato, 194.4 and 'A 71.27. Cf. E. de W. Burton, Syntax of the Moods and Tenses in New Testament

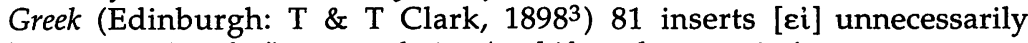
between $\kappa \alpha i$ and oü $\tau \omega \varsigma$ translating 'and if need so require'.

58'So then do take care lest in your desire to avenge...', Art of Rhetoric 1393A-B.

${ }^{59}$ Kistemaker (1 Corinthians, 251): it 'probably means that his sexual drive controls the man and compels him to marry'; $c f$. H. Conzelmann, 1 Corinthians (Philadelphia: Fortress Press, 1975) 135 who asks what is the meaning of the sentence, suggesting 'and it has to be so'. 


\section{Not to Marry}

An examination of the sets of conditions that result in the decision not to marry (1 Cor. 7:37) may further our understanding of the meaning of $\dot{v} \varepsilon \dot{\rho} \alpha \kappa \mu \mathrm{o}$. Paul appears to have arranged these as npposites to those in the previous verse (see p. 87 below). As we explored the criteria for the person who is told not to marry in the next verse (v. 37), it may well provide further help in determining whether $\dot{v} \varepsilon \dot{\varepsilon} \alpha \kappa \mu$ os refers to the woman's sexual development or the man's sexual passions, and the identity of the ones who raised the question in 1 Corinthians 7:25-fathers or fiancés?

An argument for suggesting that $\dot{v} \pi \dot{\varepsilon} \rho \kappa \mu \circ \varsigma$ relates to the woman is one of the meanings of $\gamma \alpha \mu i \zeta \varepsilon \imath$, 'to give in marriage' (1 Cor. 7:38), which is what a father did, but as Conzelmann points out, it also meant 'to marry' 60

If the reference in verse 37 is to the father of the betrothed daughter, one can understand his decision because of 'the present difficulty' in Corinth (1 Cor. 7:26) 'to stand steadfast', i.e., not let the marriage proceed by not giving the dowry and thereby withholding consent. ${ }^{61}$ But why does Paul

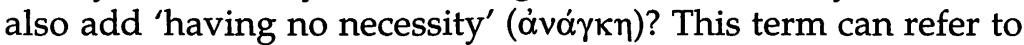
'natural need', i.e., hunger, but also has sexual references which are well attested.62 And what is to be made of the statement

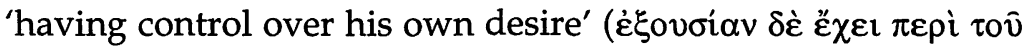

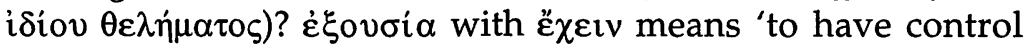
over', and $\theta \dot{\varepsilon} \lambda \eta \mu \alpha$ is used in pagan sources for 'sexual desire'.63 When Paul refers to the will of the man, he is discussing not only marriage but the person's sexuality.

${ }^{60}$ E.g., BAGD 839; Conzelmann, 1 Corinthians, 136.

${ }^{61}$ On the role of the dowry see, D.M. Schaps, 'The Dowry', Economic Rights of Women in Ancient Greece (Edinburgh: Edinburgh University Press, 1979) ch. 6, and Treggiari, 'Dos' Roman Marriage, ch. 10.

${ }^{62}$ Aeschylus, Agamemnon 1.726 , 'needs of the stomach'; Plato, Republic 458d, 'necessity to sexual union'; and Aristophanes, The Clouds ll. 1075-6, 'the wants of nature, you love, you seduce'.

${ }^{63}$ For examples and discussion, see W.G. Kümmel, 'Verlobung und Heirat bei Paulus (1 Kor 7:36-38)', in W. Eltester (ed.), Neutestamentliche Studien für Rudolf Bultmann (Berlin: Töpelmann, 1957) 283-84 and examples in $n$. 25. 
In 1 Corinthians 7:37 the person concerned can maintain a firm grip on the situation and defer the marriage, in a way the person in the previous verse could not-'being under no [sexual] necessity, and having under control his own [sexual] desire'. 'What is said in these [two] verses refers to

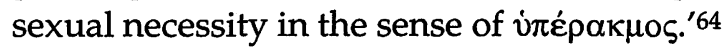

\section{Female or Male?}

Having considered the meaning of other terms and clauses in 1 Corinthians 7:36-37, we return to the issue of the referent for

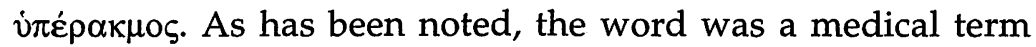
used of females who had achieved puberty, i.e., fourteen years of age. If the person to whom Paul is referring is a female, then that conclusion is important. He would be proscribing marriage for a pre-pubescent girl who has been betrothed by her parents at a very early age-a concern also noted by Soranus. The Papian Law of Augustus laid down the age for marriage for women to be between twenty and fifty, but there is evidence of marriages at an early age. 65

What is the nexus between the unseemly behaviour in the opening part of verse 36 and the end result, i.e., 'and thus it is bound to happen', bearing in mind that between them is

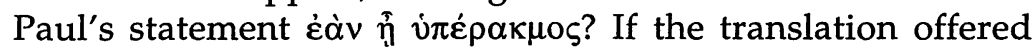

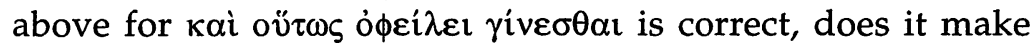
sense to say that the reason for not marrying has to do with the bride, i.e., she had not reached puberty? Rather, it has been suggested, that as a consequences of the young man's sexual impropriety which Paul sees as unseemly conduct, he is full of sexual passion which is an inevitable consequence of his behaviour. He could only awaken his own strong sexual passions because of the nature of his amorous contacts with his fiancée. Paul's assurance that a fiancé is not sinning in marrying is certainly explicable, because of the attitude of some of the Corinthians expressed in 1 Corinthians 7:1 that it is better for a man not to touch a woman.

${ }^{64}$ For the use of $\theta \dot{\varepsilon} \lambda \eta \mu \alpha$ in a sexual sense see, TWNT III. 45, and cit. 60 . ${ }^{65}$ Treggiari, Roman Marriage, 159, 398-403. 


\section{Conclusions}

Given the implication of grammatical constructions following the conditional particles عi and ćóv (if), the consequential role

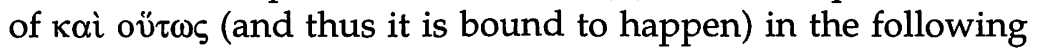
statement, and the meaning not only of i $\pi \dot{\varepsilon} \rho \alpha \kappa \mu$ s (full of passion), $\pi \alpha \rho \alpha \kappa \mu \eta$ (past one's prime), but also that of

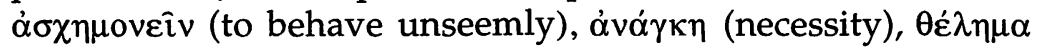
(desire) in the semantic field of sexuality, it is concluded that neither 'past childbearing age' nor 'puberty' is the appropriate translation. Instead, 'full of sexual passion' (referring to the fiancé and not the fiancée) is the apposite rendering of the term,

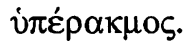

The two scenarios for the fiancé are:

verse 36

verse 37

\section{Criteria}

(i) If anyone thinks he is behaving inappropriately towards his betrothed

(ii) If he should be full of passion

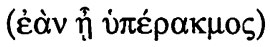

(i) The one standing steadfast in heart

(ii) having no [sexual] necessity $(\mu \grave{\eta} \varepsilon ̋ \omega v \dot{\alpha} v \alpha \dot{\gamma} \gamma \kappa \eta v)^{66}$

\section{Consequence}

and thus it is bound to happen,

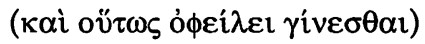

and is having control over his own [sexual] desire

\section{Resolution}

he must do what he wishes, is not sinning, they must marry

and he has determined this in he his own heart to keep his own betrothed, he will do well.

Conclusion 'so then' ( he who marries

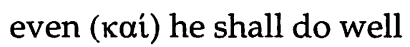
he who refrains from marriage he shall do better.

${ }^{66}$ Contra K.L. Schmidt, $\theta \dot{\lambda} \lambda \eta \mu \alpha$, TWNT III, 60 who parallels this and the

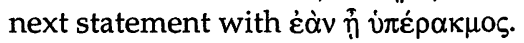




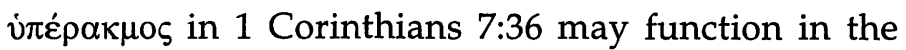

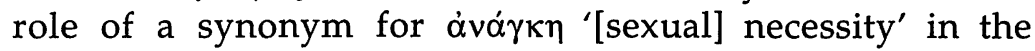
following verse. It is a synonymous noun for the infinitive of the verb, $\pi$ voó $\omega$ which occurred in his comment in 1 Corinthians 7:9 that 'it is better for the unmarried man to marry rather than "to burn [with passion]"' ( $\pi v \rho 0 v \overline{\sigma \theta \alpha l})$, for that verb carries such connotations in the description of sexual feelings. 67

It is important to reflect on the fact that there is a rich vein of material yet to be mined from the now readily accessible Greek corpus. For the first time in its history New Testament word studies are faced not with a dearth of material, but with what some may feel in certain instances, is too much evidence to investigate. Chadwick has made a personal observation with reference to what seemed to him to be difficulties in undertaking a new classical Greek lexicon and not simply a revision of Liddell and Scott's Supplement.

The collecting of examples has now been much facilitated by the IBYCUS computer system.... The danger here is the weight of material thus made available; it can easily take a day's work to scan the material for one word. It is therefore best to keep this weapon in reserve and use it selectively. 68

There may be those who would endorse such sentiments, but future serious linguistic studies in the New Testament cannot be restricted to such occasional searches of particular words. Surveys covering a century on either side of the first are an appropriate starting point, especially because word meanings in the Classical period could change substantially some four centuries later in the New Testament era.

This study has demonstrated that there is great value in using such capabilities as we now have to hand to re-examine words such as $\dot{\pi \varepsilon ́ \rho \alpha \kappa \mu \rho}$ if we are to harvest some of the pickings which can now be easily recovered by electronic means. They can help resolve the impasse experienced by

${ }^{67}$ For an example of the use of this verb in connection with the emotions

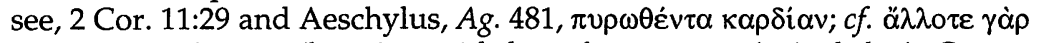

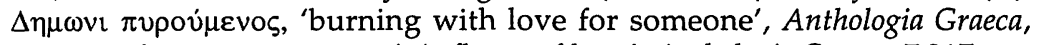
12.87, and a cognate $\pi v p \kappa \alpha i \alpha$, 'a flame of love', Anthologia Graeca, 7.217.

${ }^{68}$ Chadwick, Lexicographica Graeca, 17. 
former generations of scholars about terms judged to be either ambiguous in their referents, ${ }^{69}$ and/or difficult to understand in their meaning, and therefore their significance, in the overall argument of a passage problematic. 70

It is not always the case that problems arise because of the perceived lack of evidence. The above examination of this particular verse has highlighted the importance for New Testament linguistic studies of (1) not focusing simply on one word; (2) not building a case on the meaning of a noun and a prefix-in this case $\dot{\alpha} \kappa \mu \eta \dot{~ a n d ~} \dot{v} \varepsilon \dot{\rho}$-especially when examples of the full term are available; (3) searching for instances of a term in literary and non-literary data which is now accessible in electronic form; (4) establishing the meaning of a word in a particular semantic field as well as other key words or combination of words in the passage within the same field such

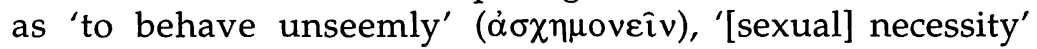
( $\alpha \dot{\alpha} \gamma \kappa \eta)$ and '[sexual] desire' $(\theta \varepsilon \dot{\varepsilon} \lambda \mu \alpha)$; (5) looking for synonyms of the actual term, and more importantly in this instance, the actual word used for being 'past one's prime' $(\pi \alpha \rho \alpha \kappa \mu \eta \dot{)})$ (6) searching for any relevant legal and social background information, so that assumptions about these by commentators can be carefully evaluated; and finally, (7) accounting for the way in which the actual argument has been constructed grammatically. ${ }^{71}$

${ }^{69}$ So in 1 Cor. $7: 36$ according to $B A G D, 839$.

${ }^{70}$ For an impressive resolution of the meaning of $\mu \hat{\alpha} \lambda \lambda$ ov $\chi \rho \hat{\eta} \sigma \alpha \mathrm{r}$ in 1 Cor. 7:21 with the use of an electronic search for examples of these two words together, see J.A. Harrill, The Manumission of Slaves in Early Christianity (Tübingen: J.C.B. Mohr [Paul Siebeck] 1995) 108-21, and for its implications, see my 'St. Paul as a Critic of Roman Slavery in 1 Corinthians 7:21-23', forthcoming Пav́leı 4 (1998).

${ }^{71}$ For a fuller discussion of the particular Sitz im Leben in Corinth at that time and Paul's extended argument in 1 Cor. 7:25-38, see forthcoming my 'The Present Crisis and Consummation of the Marriage in 1 Corinthians 7:25-38', in After Paul left Corinth: The Influence of Secular Ethics and Social Change (Grand Rapids: Eerdmans, 1998) ch. 10. 